\title{
Penerapan Model Pembelajaran Kooperatif Tipe Jigsaw Dapat Meningkatkan Kemampuan Siswa Kelas IX-1 Materi Perkembangbiakan Vegetative Pada Tumbuhan Pelajaran IPA di SMPN 6 Takengon Aceh Tengah
}

\author{
Huriah \\ Guru SMPN 6 Takengon Aceh Tengah
}

\begin{abstract}
Abstrak
Penelitian ini dilaksanakan di SMPN 6 Takengon Aceh Tengah, yang terletak di Desa Pinangan Kecamatan Kebayakan Kabupaten Aceh Tengah. Waktu penelitian dilaksanakan pada semester 2, tahun pelajaran 2014/2015 pada bulan Februari-April 2015. Subjek dalam penelitian ini adalah siswa kelas IX-1 SMPN 6 Takengon Aceh Tengah sebanyak 22 orang, dengan rincian putri sebanyak 10 orang dan putra 12 orang. Teknik pegumpulan data menggunakan instrumen berupa observasi dan dokumenter. Penelitian ini merupakan penelitian tindakan kelas (classroom action research) yang ditandai dengan adanya siklus,adapun dalam penelitian ini terdiri atas 2 siklus. Setiap siklus terdiri atas perencanaan, pelaksanaan, pengamatan dan refleksi. Penerapan pembelajaran kooperatif learning model jigsaw dapat meningkatkan kemampuan belajar siswa pelajaran IPA khususnya kompetensi dasar mengidentifikasi kelangsungan hidup makhluk hidup melalui adaptasi, perkembangbiakan dan seleksi alam bagi siswa kelas IX-1 pada semester 2 di SMPN 6 Takengon Aceh Tengah Tahun Pelajaran 2014/2015. Pada akhir siklus I, siswa yang mencapai ketuntasan belajar sebanyak 68.18\% (15 siswa), dan siswa yang belum tuntas sebanyak 31.81\% (7 siswa), sedangkan pada akhir siklus II, sebanyak 100\% (22 siswa) mencapai ketuntasan belajar. Dengan nilai rata- rata kelas siklus I : 72,5 dan rata- rata kelas siklus II 80. Adapun hasil non tes pengamatan proses belajar menunjukkan perubahan siswa lebih aktif selama proses pembelajaran berlangsung. Secara keseluruhan rata-rata kelas mencapai kenaikan sebesar 58,59\%, dan ketuntasan belajar siswa secara keseluruhan mencapai peningkatan sebesar 53\% jika dibandingkan dengan kondisi awal.
\end{abstract}

Kata Kunci : Penerapan, Model Pembelajaran, pembelajaran kooperatif, Tipe Jigsaw

\section{PENDAHULUAN}

Pembelajaran kooperatif merupakan model pembelajaran yang di dalamnya siswa bekerja dalm kelompok-kelompok kecil untuk membantu satu dan lainnya dalam belajar dan dihargai atas prestasi kolektif mereka (Slavin 1995:2). Pembelajaran di Sekolah Menengah Pertama menginginkan agar siswanya memiliki pengetahuan, pemahaman, keterampilan, serta sikap dan nilai yang sesuai dengan tujuan pendidikan secara menyeluruh mencakup ranah kognitif, afektif dan psikomotorik.

Untuk mendesain kegiatan pembelajaran yang dapat merangsang hasil belajar yang efektif dan efisien dalam setiap materi pelajaran, memerlukan model pembelajaran yang tepat dan pengorganisasian materi yang tepat. Model pembelajaran hendaknya berprinsif pada belajar aktif sehingga dalam proses belajar dan perhatian pembelajaran utama ditujukan kepada siswa yang belajar, oleh karena itu guru harus 
dapat menggunakan berbagai macam model dan pengorganisasian materi dengan tepat. Model pembelajaran yang diharapkan agar siswa mampu menemukan dan memahami konsep atau prinsip model pembelajaran kooperatif adalah model pembelajaran Jigsaw.

Model pembelajaran kooperatif tipe Jigsaw di sekolah kiranya merupakan alternatif untuk memenuhi kebutuhan siswa, sehingga dapat mengoptimalkan kemampuan, penalaran, dan keterampilannya untuk meningkatkan kemampuan belajar siswa pada mata pelajaran IPA. Selain itu berdasarkan pengamatan dan pengalaman peneliti sendiri selama ini proses pembelajaran IPA di sekolah jarang/belum menggunakan model pembelajaran kooperatif tipe Jigsaw. kemampuan belajar/kompetensi belajar merupakan hasil dari suatu usaha kegiatan yang dilakukan secara sadar untuk mendapatkan sejumlah pengetahuan dan pengalaman yang dipelajari. kemampuan belajar dalam proses belajar dan pembelajaran dapat dipandang sebagai barometer keberhasilan siswa dalam mengikuti pelajaran tertentu maupun sebagai ukuran keberhasilan guru dalam melaksanakan proses belajar pembelajaran. Hasil belajar meliputi kemampuan kognitif, afektif, dan psikomotorik.

Berdasarkan latar belakang masalah diatas, maka peneliti ingin malakukan penelitian dengan judul "Penerapan Model pembelajaran kooperatif Tipe Jigsaw dapat Meningkatkan kemampuan siswa kelas IX-1Materi Perkembangbiakan vegetative pada tumbuhan Pelajaran IPA di SMPN 6 Takengon Aceh Tengah".

\section{Tujuan Penelitian}

Tujuan penelitian ini untuk mengetahui penerapan metode Jigsaw dapat meningkatkan Kemampuan belajar siswa pada pelajaran IPA khususnya dalam penguasaan Materi Perkembangbiakan vegetative pada Tumbuhan.

\section{KAJIAN TEORI DAN HIPOTESIS TINDAKAN Pembelajaran Kooperatif}

Pembelajaran kooperatif adalah suatu strategi yang melibatkan pembentukan kelompok. Kerja kelompok merupakan bagian dan bukan hanya sekedar cara untuk mencapai tujuan. Tujuan dari belajar kooperatif adalah pencapaian hasil belajar, penerimaan keberagaman dan keterampilan sosial (Arends 2001:315).Menurut Slavin (Dimyati 1990:234) dikatakan bahwa pembelajaran kooperatif mempunyai tiga karakteristik yaitu : 1) siswa bekerja dalam tim-tim belajar kecil, 2) siswa didorong untuk saling membantu dalam mempelajari bahan yang bersifat akademik atau dalam melakukan tugas kelompok, dan 3) siswa diberi imbalan atau hadiah atas dasar prestasi.

Selanjutnya menurut Cruickshank, Bainer, dan Metcalf (1995:206-207) maupun Arends (2001:111), karakteristik pembelajaran kooperatif antara lain adalah : 1) adanya kelompok yang heterogen dalam hal kemampuan akademis, ras dan lainnya, 2) adanya tugas kelompok berupa penugasan atau proyek , 3) aturan perilaku yang diterapkan adalah "semua untuk satu, satu untuk semua", dan 4) penghargaan kelompok dibagi secara merata oleh anggota kelompok.

\section{Metode Pembelajaran jigsaw}

Jigsaw merupakan salah satu metode belajar kooperatif formal. Belajar kooperatif formal merupakan benntuk belajar kooperatif yang melibatkan siswa untuk bekerja sama dalam satu periode pelajaran hingga beberapa minggu untuk mencapai 
tujuan belajar. Siswa mengerjakan tugas dan latihan tertentu (Johnson \& Johnson 2002:322). Pendekatan Jigsaw melibatkan parsitipasi aktif individu dan kerjasama kelompok. Dengan penyusunan pelajaran sedemikian rupa sehingga setiap anggota kelompok memiliki informasi yang unik dan pengaruh tertentu. Hasil kelompok tidak lengkap bila tanpa masing-masing kelompok melakukan bagiannya. Hal tersebut diibaratkan sebagai Jigsaw puzzle yang tidak lengkap tanpa setiap kepingan digabungkan (Brophy 1998:141). Setiap anggota kelompok diberi tugas yang berbeda dan anggota kelompok lain yang memiliki tugas sama harus bekerja sama untuk menyelesaikan tugas tersebut dalam suatu kelompok yang disebut kelompok expert. Apabila tugas setiap siswa telah selesai, mereka kembali ke kelompoknya dan menjalankan tugasnya.

\section{PerkembangbiakanVegetatif pada tumbuhan.}

Perkembangbiakan pada Tumbuhan dibagi menjadi dua macam ,yaitu perkembangbiakan generative atau seksual dan vegetative atau aseksual. Perkembangbiakan generative adalah terjadinya individu baru didahului dengan peleburan sel kelamin jantan dan betina. Sedangkan vegetative adalah terjadinya indivudu baru tanpa didahului dengan peleburan sel kelamin jantan dan betina.

Perkembangbiakan (Reproduksi) vegetatif pada tumbuhan sering disebut juga propagasi vegetatif. Propagasi vegetatif dapat terjadi secara alami maupun dengan bantuan manusia.

\section{METODE PENELITIAN}

\section{Tempat Penelitian}

Penelitian ini dilaksanakan di SMPN 6 Takengon Aceh Tengah, yang terletak di Desa Pinangan Kecamatan Kebayakan Kabupaten Aceh Tengah.

\section{Waktu Penelitian}

Waktu penelitian dilaksanakan pada semester 2, tahun pelajaran 2014/2015 pada bulan Februari-April 2015.

\section{Subjek Penelitian}

Subjek dalam penelitian ini adalah siswa kelas IX-1 SMPN 6 Takengon Aceh Tengah sebanyak 22 orang, dengan rincian putri sebanyak 10 orang dan putra 12 orang.

\section{Teknik pegumpulan data}

Untuk memperoleh sejumlah data yang diperlukan dalam penelitian ini digunakan instrumen berupa observasi dan dokumenter.

\section{Prosedur Penelitian}

Penelitian ini merupakan penelitian tindakan kelas (classroom action research) yang ditandai dengan adanya siklus,adapun dalam penelitian ini terdiri atas 2 siklus. Setiap siklus terdiri atas perencanaan, pelaksanaan, pengamatan dan refleksi. 


\section{HASIL PENELITIAN DAN PEMBAHASAN Deskripsi Kondisi Awal}

Pembelajaran sebelum pelaksanaan tindakan kelas, guru mengajar secara konvensional. Guru cenderung menstranfer ilmu pada siswa tanpa menggunakan media atau metode yang cocok, sehingga siswa pasif, kurang kreatif, bahkan cenderung bosan. Disamping itu dalam menyampaikan materi guru tanpa menggunakan media pembelajaran atau metode yang cocok.

Melihat kondisi pembelajaran yang monoton, suasana pembelajaran tampak kaku, berdampak pada nilai yang diperoleh siswa kelas IX-1 pada kompetensi dasar Mengidentifikasi kelangsungan hidup makhluk hidup melalui adaptasi seleksi alam dan perkembangbiakan. sebelum siklus I (pra siklus) seperti pada tabel nilai. Banyak siswa belum mencapai ketuntasan belajar minimal dalam mempelajari kompetensi dasar tersebut. Hal ini diindikasikan pada capaian nilai hasil belajar di bawah kriteria ketuntasan minimal (KKM) sebesar 65.

Berdasarkan hasil analisis data diketahui bahwa tidak ada siswa yang mendapat nilai A (sangat baik) 0 siswa atau $0 \%$, yang mendapat nilai B (baik) sebanyak 4 siswa atau $18,18 \%$, yang mendapat nilai $\mathrm{C}$ (cukup) sebanyak 4 siswa atau $18,18 \%$, yang mendapat nilai D (kurang) sebanyak 10 siswa atau 45,45\% dan yang mendapat nilai $\mathrm{E}$ (sangat kurang) sebanyak 4 siswa atau $18 \%$.

Dari hasil tes seperti tersebut di atas, hanya sebagian siswa saja yang tuntas belajar, sedangkan sebagian lagi belum tuntas belajar.

Berdasarkan analisis data diketahui bahwa pada kondisi awal ini terdapat 8 siswa $(36,36 \%)$ yang memiliki nilai sesuai KKM sebesar 65 yang dinyatakan tuntas belajar dan 14 siswa $(63,63 \%)$ memiliki nilai dibawah KKM yang dinyatakan belum tuntas belajar.

\section{Deskripsi Hasil Siklus I}

\section{a. Perencanaan}

Perencanaan tindakan dalam siklus I dapat diuraikan sebagai berikut :

1) Pemilihan materi dan penyusunan RPP.

Materi yang dipilih dalam penelitian tindakan kelas ini adalah materi sistem Perkembangbiakan vegetative pada Tumbuhan. Berdasarkan konsep ini disusun ke dalam RPP dengan alokasi waktu sebanyak 4 x 40 menit. Pada siklus ini terjadi dua kali pertemuan.

2) Pembentukan kelompok

Pada siklus I, siswa dibagi dalam kelompok-kelompok kecil terdiri atas 3 orang perkelompok.Penentuan anggota kelompok sesuai dengan ketentuan yang telah ditentukan guru.

\section{b. Pelaksanaan}

Tatap muka I dan II dengan RPP tentang materi Perkembangbiakan vegetatif Alami pada tumbuhan. Metode pembelajaran yang digunakan adalah pembelajaran kooperatif learning tipe jigsaw dengan panduan Lembar Kerja Siswa ( LKS). Adapun langkah-langkahnya sebagai berikut;

1) Guru secara klasikal menjelaskan metode pembelajaran yang harus dilaksanakan siswa.

2) Secara kelompok siswa mencari dan mempelajari materi perkembangbiakan vegetetif Alami pada tumbuhan melalui buku pelajaran IPA kelas IX. 
3) Secara kelompok siswa mencari dan menemukan macam-macam perkembangbiakan vegetatif pada tumbuhan dengan panduan Lembar Kerja Siswa (LKS).

4) Secara kelompok siswa berdiskusi menyelesaikan LKS.

5) Secara kelompok siswa bertanya jawab antar kelompok untuk mempresentasikan hasil kerjanya.

6) Kelompok yang mendapat skor paling tinggi mendapat hadiah.

7) Guru memberi umpan balik hasil pemahaman siswa terhadap materi yang dipelajari dengan mengadakan evaluasi berupa tes.

8) Guru menilai hasil evaluasi.

9) Guru memberikan tindak lanjut.

Sekilas gambaran proses pembelajaran pada siklus I, guru tidak lagi mentransfer materi pada siswa, tapi siswa secara aktif bekerja sama dalam kelompok untuk mencari materi serta mendiskusikannya. Siswa tampak aktif dan bergairah dalam pembelajaran. Dalam kegiatan ini mereka saling bekerja sama dan bertanggung jawab untuk berkompetisi dengan kelompok lain dalam menyelesaikan lembar kerja siswa .Suasana pembelajaran lebih menyenangkan.

\section{c. Observasi}

Kegiatan pembelajaran siklus I dapat terlihat seperti gambar diatas.

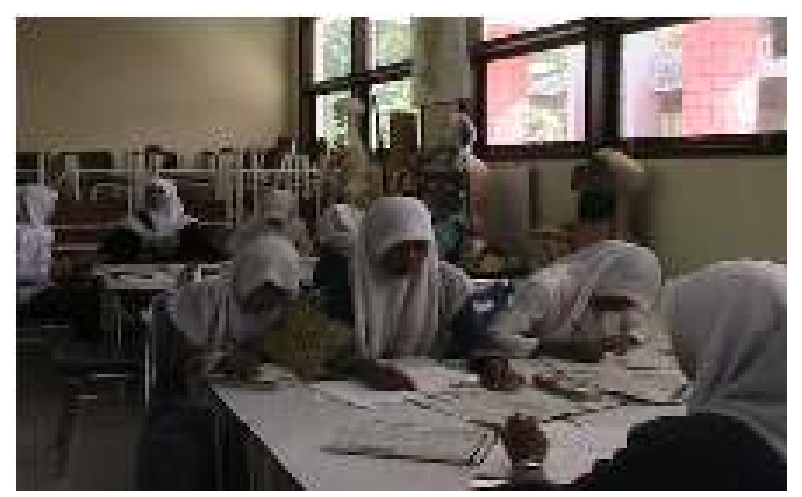

Observasi dilaksanakan pada keseluruhan kegiatan tatap muka, dalam hal ini observasi dilakukan oleh 1 (satu) pengamat yaitu salah satu guru IPA di SMP Negeri 6 Takengon (teman sejawat) dilaksanankan untuk mengetahui partisipasi aktif, tanggung jawab dalam mengikuti pelajaran, memusatkan perhatian pada pelajaran dan bekerjasama dalam kelompok untuk memahami materi perkembangbiakan vegetative padatumbuhan.

Hasil pengamatan pada siklus I menunjukkan bahwa hasil yang mencapai nilai A (sangat baik) adalah 2 siswa (9.09\%), sedangkan yang mendapat nilai B (baik) adalah 7 siswa atau (31,81 \%), sedangkan dari jumlah 22 siswa yang masih mendapatkan nilai $\mathrm{C}$ (cukup) sebanyak 6 siswa $(27,27 \%)$, sedangkan yang mendapat nilai D (kurang) ada 7 siswa $(31,81 \%$ ), sedangkan yang mendapat nilai D (sangat kurang) tidak ada atau $0 \%$.

Berdasarkan data analisis data diketahui bahwa siswa kelas IX-1 yang memiliki nilai lebih dari KKM 6,5 sebanyak 15 siswa. Dengan demikian jumlah siswa yang belum mencapai ketuntasan belajar minimum untuk kompetensi dasar Mengididentifikasi kelangsungan hidup makhluk hidup melalui adaptasi, seleksi alam, 
dan perkembangbiakan. sebanyak 7 siswa $(31,18 \%)$. Sedangkan yang telah mencapai ketuntasan sebanyak 15 siswa $(68,18 \%)$.

\section{d. Refleksi}

Berdasarkan hasil tes kemampuan awal dengan hasil tes kemampuan siklus I dapat dilihat adanya pengurangan jumlah siswa yang masih di bawah Kriteria ketuntasan Minimal. Pada pra siklus jumlah siswa yang dibawah KKM sebanyak 14 siswa dan pada akhir siklus I berkurang menjadi 7 siswa. Nilai rata-rata kelas meningkat dari 57.5 menjadi 72,5. Jumlah siswa yang mencapai ketuntasan belajar mengalami peningkatan jika dibandingkan dengan pra siklus.

Tabel Perbandingan Ketuntasan Belajar antara Pra Siklus dengan Siklus I

\begin{tabular}{|l|l|l|l|l|l|}
\hline \multirow{2}{*}{ No } & \multirow{2}{*}{ Ketuntasan } & \multicolumn{3}{|c|}{ Jumlah Siswa } \\
\cline { 3 - 6 } & & \multicolumn{3}{|c|}{ Pra Siklus } & \multicolumn{2}{c|}{ Siklus I } \\
\cline { 3 - 6 } & Jumlah & Persen & Jumlah & Persen \\
\hline 1. & Tuntas & 8 & $36,36 \%$ & 15 & $68,18 \%$ \\
\hline 2. & Belum Tuntas & 14 & $63,63 \%$ & 7 & $31,81 \%$ \\
\hline
\end{tabular}

Sumber :Tabulasi data maret 2015

Berdasarkan data pada table diatas diketahui bahwa siswa kelas IX-1 yang memiliki nilai yang lebih dari KKM 6,5 sebanyak 15(68,18 \%) siswa. Dengan demikian jumlah siswa yang belum mencapai KKM untuk kompetensi dasar mengidentifikasi kelangsungan hidup makhluk hidup melalui perkembangbiakan ,adaftasi dan seleksi alam sebanyak 7 siswa (31,81\%). Sedangkan yang telah mencapai ketuntasan sebanyak 15 siswa $(68,18 \%)$

\section{Deskripsi Hasil siklus II}

\section{a. Perencanaan}

Perencanaan tindakan dalam siklus II dapat diuraikan sebagai berikut :

1) Pemilihan materi dan penyusunan RPP.

Materi yang dipilih dalam penelitian tindakan kelas ini adalah perkembangbiakan vegetative pada tumbuhan. Berdasarkan konsep ini disusun kedalam RPP dengan alokasi waktu sebanyak 4 x 40 menit. Pada siklus ini terjadi dua kali pertemuan.

2) Pembentukan kelompok

Pada siklus II,siswa dibagi dalam kelompok-kelompok kecil terdiri dari 4 orang perkelompok. Penentuan anggota kelompok sesuai dengan keinginan siswa.

\section{b. Pelaksanaan}

Pelaksanaan tindakan pada siklus II adalah dengan pelaksanaan tatap muka. Tatap muka I dan II dengan RPP tentang materi perkembangbiakan vegetative buatan pada tumbuhan. Metode pembelajaran dengan yang digunakan adalah kooperatif dengan menggunakan tipe jigsaw dan menggunakan LKS.

Ada punlangkah-langkahnya sebagai berikut :

a).Guru memberikan evaluasi atas kegiatan pembelajaran pada siklus II.

b).Guru memberikan motivasi pentingnya model pembelajaran kooperatif tipe jigsaw dalam mempelajari materi perkembangbiakan vegetatif pada tumbuhan .

c).Membimbing sisa untuk merangkum pelajaran.

d).Guru memberikan evaluasi dengan tes.

e).Guru menilai hasil evaluasi.

Kegiatan pembelajaran siklus II dapat dilihat seperti gambar dibawah ini. 


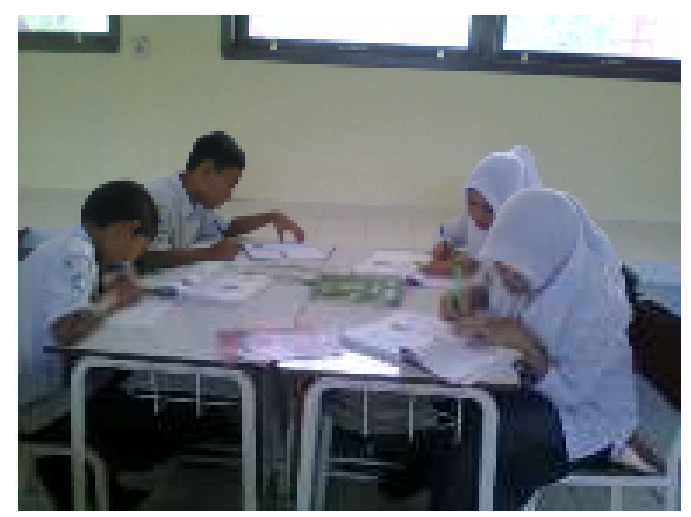

Gambar. Kegiatan pembelajaran siklus II

Suasana pembelajaran pada siklus II , lebih aktif dari pada minggu sebelumnya siswa Nampak lebih bersemangat dan termotivasi untuk menyelesaikan tugas yang diberikan guru hal ini disebabkan karena guru sudah menerapkan pembelajaran dengan menggunakan model kooperatif learning tipe jigsaw,media charta perkembangbiakan vegetative pada tumbuhan serta LKS.

\section{c. Observasi}

Observasi dilaksanakan pada keseluruhan kegiatan tatap muka,dalam hal ini observasi dilakukan oleh 1 (satu) pengamat yaitu salah satu guru bidang studi IPA di SMPN 6 Takengon (teman sejawat) dilaksanakan untuk mengetahui secara detail partipasi aktif,tanggung jawab, disiplin dalam mengikuti pelajaran,dan bekerja sama dalam kelompok untuk memahami materi perkembangbiakan vegetative pada tumbuhan.

Hasil pengamatan pada siklus II dapat diketahui bahwa yang mendapatkan nilai sangat baik (A) adalah $22,70 \%$ atau 5 siswa, sedangkan yang terbanyak yaitu yang mendapat nilai baik (B) adalah $31,81 \%$ atau 7 siswa. Dan yang mendapat nilai C (cukup) adalah 45,45\% atau sebanyak 10 siswa.Sedangkan yang mendapat nilai D dan E tidak ada. Sedangkan nilai rata-rata kelas 80 .

Berdasarkan analisis data diketahui bahwa siswa yang mencapai ketuntasan sebanyak 22 siswa (semua) (100\%) yang berarti sudah ada peningkatan.

\section{d. Refleksi}

Berdasarkan nilai hasil siklus I dan nilai hasil siklus II dapat diketahui bahwa model pembelajaran kooperatif learning tipe jigsaw dapat meningkatkan hasil belajar IPA khususnya kompetensi dasar Mengidentifikasikan kelangsungan hidup makhluk hidup melalui Adaptasi, Seleksi alam dam Perkembangbiakan.

Jika dibandingkan antara keadaan kondisi awal, siklus I dan siklus II dapat dilihat bahwa saat kondisi awal rata- rata kelas sebesar 57,5 sedangkan nilai rata- rata kelas siklus I sudah ada peningkatan menjadi 72,5. Adapun kenaikan rata - rata pada siklus II menjadi 80. Untuk lebih jelasnya dapat dilihat pada tabel dan diagram dibawah ini :

Tabel Perbandingan Hasil Nilai Tes Pra Siklus, Siklus I dan Siklus II

\begin{tabular}{|c|c|c|c|c|}
\hline \multirow{2}{*}{ No } & \multirow{2}{*}{ Hasil Tes } & \multicolumn{3}{|c|}{ Jumlah Siswa yang berhasil } \\
\cline { 3 - 5 } & & Pra Siklus & Siklus I & Siklus II \\
\hline 1 & $\mathrm{~A}(85-100)$ & 0 & 2 & 5 \\
\hline 2 & $\mathrm{~B}(75-84)$ & 4 & 7 & 7 \\
\hline
\end{tabular}




\begin{tabular}{|c|c|c|c|c|}
3 & $\mathrm{C}(65-74)$ & 10 & 6 & 10 \\
\hline 4 & $\mathrm{D}(55-64)$ & 4 & 7 & 0 \\
\hline 5 & $\mathrm{E}(<54)$ & 4 & 0 & 0 \\
\hline & Jumlah & 22 & 22 & 22 \\
\hline
\end{tabular}

Sumber : Hasil Tabulasi Data Maret 2015

Peningkatan ketuntasan belajar siswa antara hasil pra siklus, siklus I dan siklus II dapat dilihat pada tabel berikut :

Tabel Perbandingan Ketuntasan Belajar Pra Siklus dan Siklus I \& Siklus II

\begin{tabular}{|c|c|c|c|c|c|c|c|}
\hline \multirow{2}{*}{$\begin{array}{c}\text { N } \\
\text { o }\end{array}$} & \multirow{2}{*}{ Ketuntasan } & \multicolumn{6}{|c|}{ Jumlah Siswa } \\
\cline { 3 - 8 } & & \multicolumn{2}{|c|}{ Pra Siklus } & \multicolumn{2}{c|}{ Siklus I } & \multicolumn{2}{c|}{ Siklus II } \\
\cline { 3 - 8 } & Jumlah & Persen & Jumlah & Persen & Jumlah & Persen \\
\hline 1 & Tuntas & 8 & $36,36 \%$ & 15 & $52,38 \%$ & 22 & $100 \%$ \\
\hline 2 & Belum Tuntas & 14 & $63,63 \%$ & 7 & $47,62 \%$ & 0 & $0 \%$ \\
\hline \multicolumn{2}{r|}{ Jumlah } & 22 & $100 \%$ & 14 & $100 \%$ & 22 & $100 \%$ \\
\hline
\end{tabular}

Sumber :Hasil Tabulasi Data 2015.

Peningkatan hasil nilai rata-rata antara pra siklus,siklus I, dan siklus II dapat dilihat pada tabel berikut :

Tabel Perbandingan Nilai Rata-rata antara Pra Siklus, Siklus I dan \& Siklus II

\begin{tabular}{|c|c|c|c|c|}
\hline No & Keterangan Nilai & Pra Siklus & Siklus I & Siklus II \\
\hline 1 & Nilai Tertinggi & 75 & 85 & 90 \\
\hline 2 & Nilai Terendah & 50 & 60 & 70 \\
\hline 3 & Nilai Rata-rata & 57,5 & 72,5 & 80 \\
\hline
\end{tabular}

Sumber : Hasil Tabulasi Data Maret 2015.

Berdasarkan data pada tabel di atas, dapat disimpulkan bahwa pembelajaran menerapkan model pembelajaran kooperatif tipe jigsaw dengan tugas kelompok dan tugas individu lebih mampu meningkatkan kemampuan belajar, khususnya pada materi perkembangbiakan vegetative padatumbuhan. Dari data yang ada dapat dilihat bahwa nilai rata-rata mengalami kenaikan dari nilai 57,5 menjadi 72,5 dan naik menjadi 80 . Walaupun nilainya belum sangat memuaskan namun dalam penelitian ini sangat tampak ada kenaikan nilai hasil belajar siswa. Belum sangat optimalnya nilai hasil belajar ini mungkin salah satunya dipengaruhi oleh kondisi ruangan belajar yang kurang nyaman. Tetapi dari hasil observasi pada proses pembelajaran sangat tampak siswa antusias dengan kegiatan pembelajaran inovatif yang menggunakan penerapan model pembelajaran kooperatif tipe jigsaw. Siswa selalu berharap agar setiap pembelajaran dapat selalu menggunakan pembelajaran inovatif untuk mendapatkan materi diskusi dan presentasi. Dengan menggunakan media LKS siswa lebih termotivasi dalam belajar. Pada hasil pembelajaran tindakan siklus II terjadi peningkatan jumlah siswa yang mencapai ketuntasan belajar dan peningkatan kemampuan belajar siswa dibandingkan pada siklus I.

Dengan melihat perbandingan hasil tes siklus I dan siklus II ada peningkatan, baik dilihat dari ketuntasan belajar maupun hasil perolehan nilai rata- rata kelas. Dari sejumlah 22 siswa tidak ada lagi siswa yang belum mencapai ketuntasan. Ketuntasan belajar pada siklus II meningkat sebesar 9,8\% dibanding pada siklus I dan rata-rata nilai kelas meningkat sebesar 6 . Nilai tertinggi pada siklus I sebesar 85 diperoleh oleh 3 siswa sedangkan pada siklus II nilai tertinggi sebesar 90 diperoleh 3 siswa,. Nilai 
terendah pada siklus I sebesar 60 sedangkan nilai terendah pada siklus II sebesar 70 . Hal ini sangat memuaskan hasil yang diperoleh siswa mungkin bisa disebabkan oleh karena guru sudah menerapkan model pembelajaran kooperatif tipe jigsaw yang menyenangkan. Dari hasil pengamatan tampak kegembiraan dan peningkatan kemampuan belajar siswa serta motivasi belajar dari siswa.

Secara umum dari hasil pengamatan dan tes sebelum pra siklus, hingga siklus II, dapat disimpulkan bahwa melalui penerapan pembelajaran kooperatif tipe jigsaw pada materi perkembangbiakan vegetative pada tumbuhan. dapat meningkatkan kemampuan belajar siswa pada mata pelajaran IPA kela 1X-1 SMP Negeri 6 Takengon Aceh Tengah Tahun pembelajaran 2014/2015.

\section{Pembahasan}

\section{Pra Siklus I}

\section{1) Hasil Belajar}

Pada awalnya siswa kelas IX-1, nilai rata- rata pelajaran IPA rendah khususnya pada kompetensi Mengidentifikasi kelangsungan hidup makhluk hidup melalui perkembangbiakan ,adaftasi dan seleksi alam. Sebelum dilakukan tindakan guru memberi tes . Berdasarkan ketuntasan belajar siswa dari 22 siswa terdapat 8 atau 36,36 $\%$ yang baru mencapai ketuntasan belajar dengan skor standar Kriteria Ketuntasan Minimal. Sedangkan 14 siswa atau $63,63 \%$ belum mencapai kriteria ketuntasan minimal ditentukan yaitu sebesar 6,5 . Sedangkan hasil nilai pra siklus I terdapat nilai tertinggi adalah 75, nilai terendah 40, dengan rata-rata kelas sebesar 57,5.

\section{2) Proses Pembelajaran}

Proses pembelajaran pada pra siklus menunjukkan bahwa siswa masih pasif, karena tidak diberi respon yang menantang. Siswa masih bekerja secara individual, tidak tampak kreatifitas siswa maupun gagasan yang muncul. Siswa terlihat jenuh dan bosan tanpa gairah karena pembelajaran selalu monoton.

\section{Siklus I}

Hasil Tindakan pembelajaran pada siklus I, berupa hasil tes dan non tes.Berdasarkan hasil observasi yang dilakukan oleh peneliti terhadap pelaksanaan siklus I diperoleh keterangan sebagai berikut :

\section{1) Hasil Belajar}

Dari hasil tes siklus I, menunjukkan bahwa hasil yang mencapai nilai A (sangat baik) adalah 2 siswa (9,09\%), sedangkan yang mendapat nilai B (baik) adalah 7 siswa atau (31,81\%), sedangkan dari 22 siswa yang masih mendapatkan nilai $\mathrm{C}$ (cukup) sebanyak 6 siswa $(27,27 \%)$, sedangkan yang mendapat nilai D (kurang) ada 7 siswa $(31,81 \%)$, sedangkan yang mendapat nilai E (sangat kurang) tidak ada atau $0 \%$.

Berdasarkan ketuntasan belajar siswa dari 22 siswa terdapat 15 atau 68,18\% yang sudah mencapai ketuntasan belajar. Sedangkan 7 siswa atau 31,81\% belum mencapai ketuntasan. Adapun dari Hasil nilai siklus I dapat dijelaskan bahwa perolehan nilai tertinggi adalah 85 , nilai terendah 60, dengan nilai rata-rata kelas sebesar 72,5.

\section{2) Proses Pembelajaran}

Proses pembelajaran pada siklus I sudah menunjukkan adanya perubahan, meskipun belum semua siswa terlibat aktif dalam kegiatan pembelajaran. Hal ini dikarenakan kegiatan yang bersifat kelompok ada anggapan bahwa prestasi maupun 
nilai yang di dapat secara kelompok . Dari hasil pengamatan telah terjadi kreatifitas dan keaktifan siswa, karena ada interaksi antar siswa secara individu maupun kelompok , serta antar kelompok. Masing-masing siswa ada peningkatan latihan bertanya dan menjwab antar kelompok, sehingga terlatih ketrampilan bertanya jawab. Ada persaingan positif antar kelompok mereka saling berkompetisi untuk memperoleh penghargaan dan menunjukkan untuk jati diri pada siswa.

Hasil antara kondisi awal dengan siklus I menyebabkan adanya perubahan walau belum bisa optimal, hal ini ditandai dengan peningkatan jumlah siswa yang mencapai ketuntasan belajar. Dari hasil tes akhir siklus I ternyata lebih baik dibandingkan dengan tingkat ketuntasan belajar siswa pada kondisi awal atau sebelum dilakukan tindakan.

Dari hasil refleksi siklus I dapat disimpulkan bahwa melalui penerapan pembelajaran kooperatif learning tipe jigsaw siswa mengalami peningkatan baik dalam mencapai ketuntasan belajar yaitu dari 22 siswa belum tuntas pada pra siklus 14 siswa yang belum tuntas. Sedangkan nilai rata - rata kelas ada kenaikan sebesar 23,03 \% .

\section{Siklus II}

Hasil tindakan pembelajaran pada siklus II berupa hasil tes, Berdasarkan hasil observasi yang dilaksanakan oleh peneliti terhadap pelaksanaan siklus II diperoleh keterangan sebagai berikut.

\section{1) Hasil Belajar}

Dari pelaksanan tindakan siklus II dapat diketahui bahwa yang mendapatkan nilai sangat baik (A) adalah $32,70 \%$ atau 5 siswa, sedangkan yang terbanyak yaitu yang mendapat nilai cukup (C) adalah $45,45 \%$ atau 10 siswa. Dan yang mendapat nilai B (baik) adalah 31,81\% atau sebanyak 7 siswa.Sedangjkan yang mendapat nilai D dan E tidak ada. Sedangkan nilai rata-rata kelas 80 .

\section{2) Proses Pembelajaran}

Proses pembelajaran pada siklus II sudah menunjukkan semua siswa terlibat aktif dalam kegiatan pembelajaran. Hal ini dikarenakan ada interaksi antar siswa secara individu maupun kelompok, serta ada persaingan positif antar kelompok untuk penghargaan dan menunjukkan jati diri pada siswa.

Hasil antara siklusI dengan siklus II ada perubahan secara signifikan, hal ini ditandai dengan peningkatan jumlah siswa yang mencapai ketuntasan belajar. dari hasil tes akhir siklus II ternyata lebih baik dibandingkan dengan tingkat ketuntasan belajar siswa pada siklus I. Peningkatan hasil belajar maupun ketuntasan tersebut dapat disajikan pada tabel dibawah ini :

Tabel Perbandingan kegiatan dan hasil pada siklus I dan siklus II

\begin{tabular}{|c|l|l|}
\hline NO & \multicolumn{1}{|c|}{ Siklus I } & \multicolumn{1}{|c|}{ Siklus II } \\
\hline $\mathbf{1}$ & Tindaka & Tindakan \\
\hline & $\begin{array}{l}\text { pembelajaran kooperatif tipe } \\
\text { jigsaw, didesain dengan } \\
\text { panduan LKS }\end{array}$ & $\begin{array}{l}\text { Penerapan Pembelajaran kooperatif tipe } \\
\text { jigsaw dipandu dengan charta } \\
\text { perkembangbiakan vegetatif pada tumbuhan }\end{array}$ \\
\hline $\mathbf{2}$ & Hasil Belajar & Hasil Belajar \\
\hline & Ketuntasan & \multicolumn{1}{|c|}{ Ketuntasan } \\
\hline & $\sim$ Tuntas :15(68,68\%) & $\sim$ Tuntas $: 22(100 \%)$ \\
\hline & $\sim$ Belum tuntas : $7(31,81 \%)$ & $\sim$ Belum tuntas :0(0\%) \\
\hline
\end{tabular}




\begin{tabular}{|c|c|c|}
\hline & NilaiTertinggi & Nilai Tertinggi \\
\hline & Nilaiterendah & Nilai terendah \\
\hline & Nilairata- rata & Nilai rata- rata \\
\hline & & Refleksi \\
\hline & & Nilai rata- rata meningkat 8,5 \\
\hline & & $=8,5 / 65 \times 100 \%=13,07 \%$ \\
\hline 2 & Proses belajar & Proses belajar \\
\hline & $\begin{array}{l}\text { Proses pembelajaran ada } \\
\text { perubahan, siswa mulai aktif }\end{array}$ & $\begin{array}{l}\text { * Proses pembelajaran siswa aktif dan } \\
\text { kreatif }\end{array}$ \\
\hline & $\begin{array}{l}\text { Siswa terlibat langsung } \\
\text { dalam proses pembelajaran }\end{array}$ & $\begin{array}{l}\text { Siswa terlibat langsung dalam proses } \\
\text { pembelajaran, dan masing- masing siswa } \\
\text { punya tugas mandiri }\end{array}$ \\
\hline & $\begin{array}{l}\text { Siswa mencari dan } \\
\text { menemukan materi, } \\
\text { mencatat serta } \\
\text { mengkomunikasikan antar } \\
\text { teman dalam kelompok } \\
\text { maupun antar kelompok }\end{array}$ & $\begin{array}{l}\text { Siswa mencari dan menemukan } \\
\text { materi,mencatatdanmengkomunikasikanh } \\
\text { asil penyelesaian secara kompetitif antar } \\
\text { teman dalam kelompok maupun antar } \\
\text { kelompok }\end{array}$ \\
\hline & $\begin{array}{l}\text { sudah memanfaatkan media } \\
\text { pembelajaran sesuai materi }\end{array}$ & $\begin{array}{l}\text { Sudah memanfaatkan media } \\
\text { pembelajaran sesuai materi yaitu charta } \\
\text { perkembangbiakan pada tumbuhan yang } \\
\text { diperagakan }\end{array}$ \\
\hline & $\begin{array}{l}\text { Kreatifitas, kerjasama, } \\
\text { tanggung jawab mulai } \\
\text { tampak. }\end{array}$ & $\begin{array}{l}\text { Kreatifitas, kerjasama, tanggung jawab } \\
\text { dan ide, kecermatan, ketepatan dan } \\
\text { kecepatan muncul }\end{array}$ \\
\hline & $\begin{array}{l}\text { - Sebagian besar alat indera } \\
\text { aktif }\end{array}$ & $\begin{array}{l}\text { - Semua alat alat indera aktif, baik mental } \\
\text { maupun fisik }\end{array}$ \\
\hline
\end{tabular}

Dengan melihat perbandingan hasil tes siklus I dan siklus II ada peningkatan yang cukup signifikan, baik dilihat dari ketuntasan belajar maupun hasil perolehan nilai rata- rata kelas. Dari 22 siswa tidak ada lagi yang belum tuntas .Sedangkan ketuntasan ada peningkatan sebesar $68,18 \%$ dibandingkan pada siklus I

Sedangkan nilai tertinggi pada siklus I sudah ada peningkatan dengan mendapat nilai 90 sebanyak 2 siswa. Dari nilai rata- rata kelas yang dicapai pada siklus II ada peningkatan sebesar $15 \%$ dibandingkan nilai rata- rata kelas pada siklus I. Secara umum dari hasil pengamatan dan tes sebelum pra siklus, hingga siklus II, dapat disimpulkan bahwa melalui penerapan pembelajaran kooperatif tipe jigsaw dapat meningkatkan kemampuan belajar siswa pelajaran IPA kompetensi dasar mengidentifikasi kelangsungan hidup makhluk hidup melalui perkembangbiakan, adaftasi dan seleksi alam.

Dari hasil penelitian, dapat dilihat dan telah terjadi peningkatan kemampuan belajar siswa pada siswa kelas IX-1V SMPN 6 Takengon Aceh Tengah pada semester II tahun pelajaran 2014/ 2015 melalui penerapan pembelajaran kooperatif tipe jigsaw. Peningkatan nilai rata- rata yaitu 57,5 pada kondisi awal menjadi 72,5 pada siklus I dan menjadi 80 pada siklus II. Nilai rata-rata siklus I meningkat $15 \%$ dari kondisi awal, nilai rata-rata siklus II meningkat $8 \%$ dari siklus I. 
Pada akhir pembelajaran terdapat perubahan positif pada siswa mengenai materi perkembangbiakan vegetative pada tumbuhan. Dengan menggunakan pembelajaran Kooperatif tipe jigsaw ternyata mampu meningkatkan kemampuan belajar siswa kelas IX-1 pelajaran IPA pada kompetensi dasar mengidentifikasi kelangsungan hidup makhluk hidup melalui perkembangbiakan, adaptasi dan seleksi alam.

\section{Kesimpulan}

Penerapan Pembelajaran Kooperatif model jigsaw dapat meningkatkan kemampuan belajar siswa pelajaran IPA khususnya kompetensi dasar Mengidentifikasi Kelangsungan hidup makhluk hidup melalui adaftasi, perkembangbiakan dan seleksi alam bagi siswa kelas IX-1 pada semester 2 di SMPN 6 Takengon Aceh Tengah Tahun Pelajaran 2014/2015. Pada akhir siklus I, siswa yang mencapai ketuntasan belajar sebanyak 68.18\% (15 siswa), dan siswa yang belum tuntas sebanyak 31.81\% (7 siswa ), sedangkan pada akhir siklus II, sebanyak 100\% (22 siswa) mencapai ketuntasan belajar. Dengan nilai rata- rata kelas siklus I : 72,5 dan rata- rata kelas siklus II 80. Adapun hasil non tes pengamatan proses belajar menunjukkan perubahan siswa lebih aktif selama proses pembelajaran berlangsung. Secara keseluruhan rata-rata kelas mencapai kenaikan sebesar 58,59\%, dan ketuntasan belajar siswa secara keseluruhan mencapai peningkatan sebesar 53\% jika dibandingkan dengan kondisi awal.

\section{DAFTAR PUSTAKA}

Anitah,2008. Strategi Pembelajaran . Jakarata. Universitas Terbuka

Anita, Lie. 2002. Coorperative Learning. Jakarta Grasindo.

Arikunto, Suharsini, 1991. Prosedur Penelitian : Suatu Pendekatan Praktek. Jakarta Rineka Cipta

BNSP, 2007. Standar Kompetensi dan kompeternsi Dasar . Jakarta. Depdiknas

BNSP , 2007. Pedoman Penilaian Hasil Belajardi SMP . Jakarta. Depdiknas.

Budimansyah Dasim. 2002 Model Pembelajaran dan Penilaian. Siliwangi. HDB

Dahar, RW. 1998. Teori-teori Belajar. Jakarta. Depdikbud

Dimyati dan Mudjiono, 1992. Strategi Belajar Mengajar. Jakarta. Depdikbud.

Dinas Prop Jateng, 2004. Model- model Pembelajaran dan Penilaian. Makalah disampaikan pada Bintek Guru SMP bidang studi Fisika

Dewi Ganawati,dkk.2008. Pembelajaran Ilmu Pengetahuan Alam Terpadu \&Kontekstual IX Untuk sekolah menengah dan madrasah tsawiyah.Jakarta.Pusat Perbukuan Dep Pend Nasianal.

Hidayat Komarudin,2002.Active Learning. Yogyakarta. Yappendi

Pahyono, dkk. 2005. Strategi Pembelajaran efektif, Model pembelajaran Kooperatif Learning. Makalah disampaikan pada diklat guru kurikulum KBK di LPMP Jawa Tengah.

Oemar Hamalik.1993. Metode Mengajar dan Kesulitan-Kesulitan Belajar. Bandung: Tarsito.

Tim abdi guru,2006.IPA TERPADU, Untuk SMP/MTS Kelas IX. Penerbit Erlangga : Jakarta. 